(c) American Dairy Science Association, 2003.

\title{
Short Communication: Effects of a Monensin Premix on Milk Fatty Acid Content During Subacute Ruminal Acidosis in Dairy Cows
}

\author{
T. Mutsvangwa, ${ }^{\star}$ J. K. G. Kramer,† C. B. Blackadar,† T. F. Duffield,‡ \\ R. Bagg, $\|$ P. Dick, $\|$ G. Vessie, $\|$ and B. W. McBride* \\ *Department of Animal and Poultry Science, University of Guelph, \\ Guelph, ON, Canada N1G 2W1 \\ †Food Research Program, Agriculture and Agri-Food Canada, \\ Guelph, ON, Canada N1G 5C9 \\ ‡Department of Population Medicine, University of Guelph \\ |Elanco Animal Health/Provel Division, Eli Lilly Canada Inc., \\ Research Park Centre, Guelph, ON, Canada N1G 4T2
}

\section{ABSTRACT}

The effects of a monensin premix on milk fatty acid content during grain-induced subacute ruminal acidosis (SARA) in Holstein cows receiving a total mixed ration was investigated. Six multiparous, rumen-fistulated Holstein cows were used in a two-treatment, two-period crossover design with 6 -wk periods. Experimental treatments were either a monensin premix or a placebo premix. At the beginning of wk 4, SARA was induced in experimental cows for a 10-d period using a grain challenge model. The administration of a monensin premix elevated milk fat proportion of total short-chain saturated fatty acids ( $\mathrm{sum}$ of $\mathrm{C}_{4}$ to $\mathrm{C}_{15}$ ). Milk fat proportions of conjugated linoleic acid isomers were unaffected. Linolenic acid $\left(\mathrm{C}_{18: 3 n 3}\right)$ proportion in milk fat of monensin-treated cows were lower when compared with placebo-treated cows during the SARA period. Results from this study indicate that dietary supplementation with monensin during SARA had little effect on milk fatty acid content.

(Key words: dairy cow, monensin, ruminal acidosis, milk fatty acids)

Abbreviation key: FA = fatty acids, PUFA = polyunsaturated fatty acids, SARA = subacute ruminal acidosis, SCSFA = short-chain saturated fatty acids

Dairy cows that are fed lactational diets rich in readily fermentable carbohydrates commonly experience subacute ruminal acidosis (SARA), a digestive disorder that is characterized by low ruminal $\mathrm{pH}$ (usually <5.6) (Owens et al., 1998). In beef feedlot diets,

Received April 17, 2003.

Accepted July 18, 2003

Corresponding author: B. W. McBride; e-mail: bmcbride@ uoguelph.ca. monensin, an ionophore, is routinely added because it attenuates ruminal acidosis (Cooper and Klopfenstein, 1996). In transition dairy cows, Green et al. (1999) reported that monensin increased ruminal $\mathrm{pH}$. Monensin exerts its effects primarily by altering ruminal fermentation pattern, including a decrease in acetate and butyrate production, and an increase in propionate production (Schelling, 1984). In addition, limited studies have indicated that monensin interferes with ruminal lipid metabolism by inhibiting lipolysis and biohydrogenation of dietary unsaturated fatty acids (FA) (Fellner et al., 1997), thereby increasing the content of unsaturated FA content in ruminal bacteria (Wakita et al., 1989) and the flow of unsaturated FA to postruminal sites (Kobayashi et al., 1992). Due to decreased ruminal biohydrogenation of dietary unsaturated FA with monensin supplementation, Sauer et al. (1998) reported a decrease in saturated FA concentration and an increase in $\mathrm{C}_{18: 1}$ content of milk fat in dairy cows fed monensin. Additionally, high concentrate diets have also been reported to depress lipolysis and biohydrogenation of dietary unsaturated FA by ruminal contents in vitro (Van Nevel and Demeyer, 1996). The objective of the present experiment was to determine the effects of monensin on milk FA composition in dairy cows that were subjected to SARA. As both monensin and SARA have been reported to inhibit ruminal lipolysis and biohydrogenation, and monensin supplementation has also been reported to attenuate SARA, we anticipated that dietary supplementation with monensin in dairy cows subjected to SARA would increase lipolysis and biohydrogenation, thereby increasing milk concentrations of short-chain saturated FA (SCSFA) and decreasing milk concentrations of polyunsatuarated FA (PUFA).

Six multiparous Holstein dairy cows $(668 \pm 46 \mathrm{~kg}$ BW; $150 \pm 53$ DIM) were used in this study. Animals were cared for and handled in accordance with the 
Canadian Council on Animal Care regulations, and the University of Guelph Animal Care Committee approved their use for this experiment. The experimental procedures have already been described (see Mutsvangwa et al., 2002). Briefly, the experiment was run as a two-treatment, two-period crossover design with 6wk periods. Experimental treatments were either a monensin premix (RUMENSIN, Elanco, Division Eli Lilly Canada Inc., Guelph, ON) or a control premix. Diet composition and chemical analysis and feeding management were conducted as described by Mutsvangwa et al. (2002). Between d 22 and 32 of each experimental period, SARA was induced by feeding additional grain as described by Mutsvangwa et al. (2002).

During the 10-d SARA period, milk samples were collected without preservative daily from morning and afternoon milkings and stored at $-20^{\circ} \mathrm{C}$. At the end of each period, frozen milk samples were thawed in a $38^{\circ} \mathrm{C}$ water bath and mixed according to AOAC (1990) method 925.21. Milk samples were pooled daily based on morning and afternoon milk yields for each cow. For milk FA analysis, total milk fat was extracted with chloroform/methanol/water in the ratio of $1: 1: 0.9$ as described by Bligh and Dyer (1959). The total lipids were methylated using $\mathrm{NaOCH}_{3}$ as catalyst (Kramer et al., 1997; Chouinard et al., 1999) and analyzed directly by gas chromatography. A Hewlett-Packard, model 5890 Series II GC (Palo Alto, CA) was used, equipped with a flame-ionization detector, a $100-\mathrm{m}$ CP Sil 88 column (Chrompack Inc., Middelburg, The Netherlands), an autosampler and a computer software system (Hewlett-Packard ChemStation A.07), and operated in a split-less mode $(0.3 \mathrm{~s})$, with inlet and detector temperatures set at $250^{\circ} \mathrm{C}$, and a temperature program from 45 to $215^{\circ} \mathrm{C}$ [ $45^{\circ} \mathrm{C}$ (hold $4 \mathrm{~min}$ ), rate of $13^{\circ} \mathrm{C} / \mathrm{min}$ to $175^{\circ} \mathrm{C}$ (hold for $27 \mathrm{~min}$ ), rate of $4^{\circ} \mathrm{C}$ to $215^{\circ} \mathrm{C}$ (hold for $35 \mathrm{~min}$ )]. The FA methyl esters and the methyl esters of conjugated linoleic acids were identified by comparison with standards from $\mathrm{Nu}$ Chek Prep (Elysian, MN), and complementary techniques (Kramer et al., 2001).

Analysis of variance was conducted using the SAS general linear models procedure (SAS, 1990) using the following general model:

$$
\mathrm{Y}_{\mathrm{ijk}}=\mu+\alpha_{\mathrm{i}}+\beta_{\mathrm{j}}+\pi_{\mathrm{k}}+\varepsilon_{\mathrm{ijk}},
$$

where $Y_{\mathrm{ijk}}=$ the dependent variable, $\mu$ = overall mean, $\alpha_{\mathrm{i}}=$ effect of cow $(\mathrm{i}=1 \ldots .6), \beta_{\mathrm{j}}=$ effect of period $(\mathrm{j}=1$, $2), \pi_{\mathrm{k}}=$ effect of treatment $(\mathrm{k}=1,2)$, and $\varepsilon_{\mathrm{ijk}}=$ random residual error. Effects were considered significant at a probability $P<0.05$, unless otherwise indicated.
Results on DMI and milk production parameters have already been published (see Mutsvangwa et al., 2002). Briefly, supplementation with monensin premix increased DMI (21.3 vs. $19.8 \mathrm{~kg} / \mathrm{d} ; P=0.03)$ and milk yield ( 31.0 vs. $27.0 \mathrm{~kg} / \mathrm{d} ; P=0.04)$. Milk fat content $(3.18$ vs. $3.38 \%)$ was lower $(P=0.03)$ in monensintreated cows compared with control cows; however, milk fat yield ( 0.98 vs. $0.88 \mathrm{~kg} / \mathrm{d})$ was unaffected $(P=$ 0.12 ) by the administration of monensin (Mutsvangwa et al., 2002). The dietary addition of monensin increased $(P=0.02)$ milk fat proportion of total SCSFA (sum of $\mathrm{C}_{4}$ to $\mathrm{C}_{15}$ ) compared with control cows (Table 1). We had anticipated that dietary supplementation with monensin in dairy cows subjected to SARA would attenuate the condition (i.e., SARA), thereby increasing ruminal lipolysis and biohydrogenation. Such a response would be expected to increase milk fat proportions of saturated FA. In the present study, only the milk fat proportion of SCSFA was increased by feeding monensin; however, these SCSFA are mainly derived from de novo synthesis in the mammary gland from acetate and $\beta$-hydroxybutyrate (Kennelly and Glimm, 1998). In addition, all indicators of SARA that we measured, including mean ruminal $\mathrm{pH}$, minimum ruminal $\mathrm{pH}$ and duration of time when ruminal $\mathrm{pH}<6$ and $<$ 5.6 , were not different between control and monensintreated cows (see Mutsvangwa et al., 2002), suggesting that monensin was ineffective in attenuating SARA. Therefore, the mechanism for increased SCSFA proportion in milk fat of monensin-treated cows is unclear. It is plausible that there was some unknown interaction between monensin and SARA such that monensin provided a prophylactic effect that allowed a more rapid adaptation to grain feeding (Mutsvangwa et al., 2002), thereby minimizing the depression in ruminal lipolysis and biohydrogenation of dietary unsaturated FA.

The administration of monensin had no effect on total milk fat proportions of $\mathrm{C}_{18: 1}$ trans $(P=0.80)$ and $\mathrm{C}_{18: 1}$ cis $(P=0.42)$ isomers (Table 1$)$. Total milk fat proportions of conjugated isomers of $\mathrm{C}_{18: 2}$ (CLA; $P=$ $0.39)$, and $\mathrm{C}_{18: 2}$ cis-9, trans-11 $(P=0.22)$ and $\mathrm{C}_{18: 2}$ trans10, cis-12 $(P=0.64)$ were not affected by the dietary addition of monensin (Table 1 ). In previous research where milk fat depression has been observed in dairy cows, the CLA isomer trans-10, cis-12 has been identified as causing the milk fat depression (see Baumgard et al., 2000). In the present study, we observed a lower milk fat content in monensin-treated cows $(3.18 \%)$ compared with control cows $(3.38 \%)$ (see Mutsvangwa et al., 2002), but it is not clear what is responsible for this inhibition of milk fat synthesis because milk fat concentration of the CLA isomer trans-10, cis-12 was unaffected by the addition of mo- 
Table 1. Milk fatty acids profile (expressed as $\mathrm{g} / 100 \mathrm{~g}$ of milk fat) during subacute ruminal acidosis in Holstein dairy cows as affected by supplementation with rumensin premix.

\begin{tabular}{lccll}
\hline Fatty acids & Control & Rumensin & SE & $P$ Value \\
\hline $\mathrm{C}_{4: 0}$ to $\mathrm{C}_{15: 0}$ & 26.52 & 27.57 & 0.19 & 0.02 \\
$\mathrm{C}_{16: 0}$ & 28.20 & 28.92 & 0.31 & 0.18 \\
$\mathrm{C}_{16: 1}$ & 1.69 & 1.63 & 0.07 & 0.61 \\
$\mathrm{C}_{17: 0}$ & 0.60 & 0.59 & 0.02 & 0.86 \\
$\mathrm{C}_{17: 1}$ & 0.23 & 0.19 & 0.02 & 0.35 \\
$\mathrm{C}_{18: 0}$ & 8.43 & 7.98 & 0.28 & 0.32 \\
$\mathrm{C}_{18: 1}$, trans & 4.06 & 4.14 & 0.19 & 0.80 \\
$\mathrm{C}_{18: 1}$, cis & 19.81 & 19.52 & 0.23 & 0.42 \\
$\mathrm{C}_{18: 2}$, conjugated (CLA) & & & & \\
Total & 0.73 & 0.77 & 0.03 & 0.39 \\
$c 9, t 11$ & 0.57 & 0.63 & 0.03 & 0.22 \\
$t 10, c 12$ & 0.020 & 0.019 & 0.001 & 0.64 \\
$\mathrm{C}_{18: 2 \mathrm{n} 6}$ & 2.40 & 2.36 & 0.06 & 0.65 \\
$\mathrm{C}_{18: 3 \mathrm{n} 3}$ & 0.41 & 0.36 & 0.01 & 0.01 \\
$\mathrm{C}_{20: 5 \mathrm{n} 3}$ & 0.024 & 0.020 & 0.002 & 0.15 \\
$\mathrm{C}_{22: 6 \mathrm{n} 3}$ & 0.018 & 0.017 & 0.001 & 0.64 \\
\hline
\end{tabular}

nensin. There is the possibility that the mechanism for milk fat depression in monensin-treated cows involved changes in precursor supply, as reflected by a lower acetate:propionate ratio in ruminal contents (see Mutsvangwa et al., 2002), rather than inhibition of de novo fat synthesis by CLA isomers. Milk fat proportion of linoleic acid $\left(\mathrm{C}_{18: 2 n 6}\right)$ was not affected by the addition of monensin, but milk fat proportion of linolenic acid $\left(\mathrm{C}_{18: 3 n 3}\right)$ was lower in monensin-treated cows compared with placebo-treated cows. Long-chain PUFA in milk originate from uptake of preformed FA from blood that are absorbed from the rumen (Kennelly and Glimm, 1998). Long-chain PUFA like $\mathrm{C}_{18: 3 \mathrm{n} 3}$ are subjected to ruminal biohydrogenation in the rumen (Kepler and Tove, 1967), with the major end-product being $\mathrm{C}_{18: 0}$ (Loor et al., 2002). Results from the present study suggest that monensin supplementation decreased $\mathrm{C}_{18: 3 \mathrm{n} 3}$ supply to the mammary gland, presumably by increasing the rate of ruminal biohydrogenation of $\mathrm{C}_{18: 3 \mathrm{n} 3}$, but unchanged milk fat proportion of $\mathrm{C}_{18: 0}$ in monensin-treated cows does not lend support to this suggestion. In summary, the administration of a monensin premix had little effect on milk FA profiles when cows were subjected to SARA.

\section{ACKNOWLEDGMENTS}

The authors would like to thank the staff of the Elora Dairy Research Centre (University of Guelph) for their technical assistance and Elanco Animal Health, Division Eli Lilly Canada Inc. (Guelph, ON, Canada) for financial support. We also would like to acknowledge the continued support for BWM that is received from the Ontario Ministry of Agriculture, Food and Rural Affairs (OMAFRA) and the Natural Sciences and Engineering Research Council of Canada (NSERC).

\section{REFERENCES}

Association of Official Analytical Chemists. 1990. Official Methods of Analysis. 15th ed. AOAC, Arlington, VA.

Bligh, E. G., and W. J. Dyer. 1959. A rapid method of total lipid extraction and purification. Can. J. Biochem. Physiol. 37:911-917.

Baumgard, L. H., B. A. Corl, D. A. Dwyer, A. Saebo, and D. E. Bauman. 2000. Identification of the conjugated linoleic acid isomer that inhibits milk fat synthesis. Am. J. Physiol. 278:R179-R184.

Chouinard, P. Y., L. Corneau, D. M. Barbano, L. E. Metzger, and D. E. Bauman. 1999. Conjugated linoleic acids alter fatty acid composition and inhibit milk fat secretion in dairy cows. J. Nutr. 129:1579-1584.

Cooper, R., and T. J. Klopfenstein. 1996. Effect of Rumensin and feed intake variation on ruminal pH. Pages A1-A14 in Scientific Update on Rumensin/Tylan/Micotil for the Professional Feedlot Consultant. Elanco Animal Health, Indianapolis, IN.

Fellner, V., F. D. Sauer, and J. K. G. Kramer. 1997. Effect of nigericin, monensin and tetronasin on biohydrogenation in continuous flowthrough ruminal fermenters. J. Dairy Sci. 80:921-928.

Green, B. L., B. W. McBride, W. D. Sandals, K. E. Leslie, R. Bagg, and P. Dick. 1999. The impact of the monensin controlled release capsule upon subclinical acidosis in the transition dairy cow. J. Dairy Sci. 82:333-342.

Kennelly, J. J., and D. R. Glimm. 1998. The biological potential to alter the composition of milk. Can. J. Anim. Sci. 78 (Suppl.):23-56.

Kepler, C. R., and S. B. Tove. 1967. Biohydrogenation of unsaturated fatty acids. III. Purification and properties of a linoleate delta 12-cis, delta 11-trans-isomerase from Butyrivibrio fibrisolvens. J. Biol. Chem. 242:5686-5692.

Kobayashi, Y., M. Wakita, and S. Hoshino. 1992. Effects of the ionophore salinomycin on nitrogen and long-chain fatty acid profiles of digesta in the rumen and duodenum of sheep. Anim. Feed Sci. Technol. 36:67.

Kramer, J. K. G., C. Cruz-Hernandez, and J. Zhou. 2001. Conjugated linoleic acids and octadecenoic acids: Analysis by GC. Eur. J. Lipid Sci. Technol. 103:600-609.

Kramer, J. K. G., V. Fellner, M. E. R. Dugan, F. D. Sauer, M. M. Mossoba, and M. P. Yurawecz. 1997. Evaluating acid and base catalysts in the methylation of milk and rumen fatty acids with special emphasis on conjugated dienes and total trans fatty acids. Lipids 32:1219-1228.

Loor, J. J., J. H. Herbein, and C. E. Polan. 2002. Trans18:1 and 18:2 isomers in blood plasma and milk fat of grazing cows fed a grain supplement containing solvent-extracted or mechanically-extracted soybean meal. J. Dairy Sci. 85:1197-1207. 
Mutsvangwa, T., J. P. Walton, J. C. Plaizier, T. F. Duffield, R. Bagg, P. Dick, G. Vessie, and B. W. McBride. 2002. Effects of a monensin controlled-release capsule or premix on attenuation of sub-acute ruminal acidosis in dairy cows. J. Dairy Sci. 85:3454-3461.

Owens, F. N., D. S. Secrist, W. J. Hill, and D. R. Gill. 1998. Acidosis in cattle: A review. J. Anim. Sci. 76:275-286.

SAS User's Guide. Statistics. Version 6 Edition. 1990. SAS Inst., Inc., Cary, NC.

Sauer, F. D., V. Fellner, R. Kinsman, J. K. Kramer, H. A. Jackson, A. J. Lee, and S. Chen. 1998. Methane output and lactation re- sponse in Holstein cattle with monensin or unsaturated fat added to the diet. J. Anim. Sci. 76:906-914.

Schelling, G. T. 1984. Monensin mode of action in the rumen. J. Anim. Sci. 58:1518-1527.

Van Nevel, C. J., and Demeyer, D. I. 1996. Influence of $\mathrm{pH}$ on lipolysis and biohydrogenation of soybean oil by rumen contents in vitro. Reprod. Nutr. Dev. 36:53-63.

Wakita, M., R. Sakauchi, and S. Hoshino. 1989. Salinomycin alters cellular fatty acid composition of mixed rumen bacteria and genus Entodinium ciliates. J. Gen. Appl. Microbiol. 35:327. 